\title{
К.лініко-патогенетичне значення показників прозапальних цитокінів у хворих на бешиху
}

\begin{abstract}
Мета роботи: визначення патогенетичного та клінічного значення прозапальних цитокінів у хворих на різні форми бешихи. Матеріали і методи. Ретроспективно і проспективно проаналізовано 114 історій хвороб пацієнтів, які проходили стаціонарне лікування в центрі гнійно-септичної хірургії КНП “Міська лікарні № 3” м. Запоріжжя впродовж 2019-2020 рр.

За формам захворювання хворих розподілили так: еритематозна - 24 (21,0 \%), бульозна - 28 (24,6 \%), флегмонозна форма - 48 (42,1 \%), некротична - 14 (12,3 \%). У 21 пацієнта встановлено рецидиви захворювання; 3 них: при еритематозній формі - 4 (16,7 \%), при бульозній - 5 (17,9 \%), флегмонозній - 9 (18,7 \%), некротичній - 3 (21,4 \%).

Результати досліджень та їх обговорення. Встановлено закономірності динаміки змін прозапальних цитокінів IL-1 $\beta$, IL-6 i TNF- $\alpha$ при різних формах бешихи. Динаміка змін вмісту цитокінів у сироватці крові у хворих на бешиху свідчить про залежність дисбалансу цих показників від тяжкості запального процесу.

При деструктивних формах бешихи виявлено достовірне підвищення IL-1 $\beta$, TNF- $\alpha$, IL-6 (p<0,05), у гострому періоді хвороби порівняно з еритематозною, що є одним з важливих патогенетичних механізмів у розвитку місцевого гнійного вогнища інфекції. У хворих із первинною еритематозною та деструктивними формами встановлено достовірне $(\mathrm{p}<0,05)$ підвищення рівнів IL-1 $\beta$, TNF- $\alpha$ та IL-6 порівняно з рецидивуючими формами.
\end{abstract}

Ключові слова: бешиха; цитокіни; запалення.

Постановка проблеми і аналіз останніх досліджень та публікацій. На сьогодні захворюваність на бешиху є високою без тенденції до зниження, посідає значне місце в структурі тимчасової втрати працездатності аж до інвалідизації, знижуючи якість життя [1].

У структурі захворюваності спостерігається тенденція до збільшення числа пацієнтів молодого і середнього віку. Більш ніж у 60 \% випадків бешиху діагностують у пацієнтів віком 40 років та старше, хворіють переважно жінки. При цьому спостерігається перехід гострих форм у хронічні, змінюється клінічний перебіг убік зростання рівня тяжкості інфекції і розвитку ускладнень [4].

Дедалі частіше спостерігається зміна клінічної симптоматики та перебігу захворювання з розвитком тяжких ускладнень та сепсису. В структурі пацієнтів із гнійно-некротичними ускладненнями, це хворі з деструктивними формами бешихи, які складають від 6,7 до 21 \%. Летальність серед пацієнтів із некротичною формою хвороби коливається в межах від 5,8 до 81 \% [2].

Провідну роль в ініціації реакції клітинного і гуморального ланок імунітету відіграє викид активованими макрофагами регуляторних прозапальних цитокінів IL-1 $\beta$, TNF- $\alpha$ i IL-6. $€$ дані про роль цих цитокінів у розвитку бешихи, оскільки формування серозного або серозно-геморагічного запалення як відповідь на впровадження в структури шкіри $\beta$-гемолітичного стрептококу відбува- ється в процесі тісної взаємодії цього мікроорганізму з макрофагальною системою, клітини якої якраз і $є$ головними продуцентами цитокінів [3].

Цитокіни відіграють важливу роль у розвитку і перебігу бешихи та виконують роль як чинника агресії, так і захисту. При цьому їхній вміст залежить від етіологічного фактора, стадії, тривалості хронічного запального і деструктивного захворювання, а також ефективності проведеної терапії, визначаючи перебіг і результат патологічного процесу [6].

Цитокіни являють собою низькомолекулярні білки, ендогенні біологічно активні медіатори, що регулюють міжклітинні взаємодії. Ці регуляторні пептиди становлять початкову ланку активації імунної відповіді і визначають ефективність і тип імунного реагування на інфекційні та неінфекційні агенти.

IL-1ß відіграє ключову роль у розвитку і регуляції неспецифічного захисту та специфічного імунітету. У хворих на сепсис він стимулює та регулює запальні і імунологічні процеси, підвищує фагоцитоз, має цитотоксичну та бактерицидну активність, бере участь у температурній реакції організму [5].

TNF- $\alpha$ є одним $з$ цитокінів, що формує реакцію гострої фази запалення. Його підвищення на ранніх стадіях запального процесу корелює з його прогресуванням. Незважаючи на високу концентрацію TNF- $\alpha$ можна розглядати, з одного боку, як 
механізм самозахисту, з іншого - його гіперпродукція спричиняє в організмі розвиток тяжких патологічних реакцій [7].

IL-6 корелює зі ступенем активності запалення, він індукує синтез імуноглобулінів, у тому числі автоантитіл і білків гострої фази, але не може їх інтегрувати [8].

$€$ повідомлення, що у хворих на бешиху спостерігаються зміни показників вмісту цитокінів, але ці дані досить суперечливі.

Мета роботи: визначення патогенетичного та клінічного значення прозапальних цитокінів у хворих на різні форми бешихи.

Матеріали і методи. Ретроспективно і проспективно проаналізовано 114 історій хвороб пацієнтів, які перебували на стаціонарному лікуванні в центрі гнійно-септичної хірургії КНП “Міська лікарні № 3” м. Запоріжжя за період 2019-2020 pр.

За формами захворювання хворих розподілили таким чином: еритематозна - 24 (21,0 \%), бульозна - 28 (24,6 \%), флегмонозна форма - 48 (42,1 \%), некротична - 14 (12,3 \%). Рецидивні випадки захворювання встановлено у 21 пацієнтів; 3 них: при еритематозній формі - 4 (16,7 \%), при бульозній - 5 (17,9 \%), флегмонозній - 9 (18,7 \%), некротичній - 3 (21,4 \%).

У гендерному відношення: чоловіків - 47 (41,2 \%), жінок - 67 (58,8 \%). Вік пацієнтів склав $(62,1 \pm 2,6)$ року.

Серед супутньої патології найчастіше зустрічалися ішемічна хвороба серця, атеросклеротичний кардіосклероз, гіпертонічна хвороба, цукровий діабет, варикозна хвороба нижніх кінцівок та ін.

Визначення цитокінів у сироватці крові здійснювали за допомогою тест-систем для ІФА-діагностики виробництва “Вектор-Бест” (Україна) на кафедрі лабораторної діагностики та загальної патології ДЗ “Запорізька державна медична академія післядипломної освіти МОЗ України”. Дослідження проводили в динаміці: при госпіталізації, на 7-8 і 12-16 добу.

Статистичну обробку даних проводили з урахуванням принципів доказової медицини, розрахунки виконували з використанням програмного пакета для статистичного аналізу даних StatSoft “STATISTICA 6.1” №AXXR712D833214FAN5.

Результати досліджень та їх обговорення. При дослідженні рівня IL-1 $\beta$ у хворих бешихою залежно від характеру місцевого осередку ми спостерігали достовірне підвищення цього показника впродовж усього періоду захворювання як у хворих з еритематозною формою, так і у хворих із деструктивними формами $(\mathrm{p}<0,05)$. У гострому періоді захворювання у хворих 3 деструктивними формами бешихи показники рівня IL-1 $\beta$ достовірно перевищували аналогічні показники у хворих 3 еритематозною формою $((112,0 \pm 27,8)$ пг/мл та $(49,9 \pm 10,8)$ пг/мл відповідно).

При аналізі показників TNF- $\alpha$ у хворих бешихою залежно від характеру місцевого осередку ми встановили достовірне підвищення рівня TNF- $\alpha$ у хворих з еритематозною формою бешихи тільки в гострому періоді захворювання $(\mathrm{p}<0,05)$, на 7-8 добу показники TNF- $\alpha$ знижувалися до нормальних значень (p>0,05). Рівень TNF- $\alpha$ у хворих із деструктивними формами бешихи перевищував нормальні значення впродовж усього періоду захворювання (в гострому періоді ці показники мали значення $(66,8 \pm 22,3)$ пг/мл і $(42,9 \pm 8,5)$ пг/мл відповідно, а в період ранньої реконвалесценції склали $(22,6 \pm 4,6)$ пг/мл і $(10,3 \pm 3,2)$ пг/мл відповідно) $(\mathrm{p}<0,05)$ (табл. 1).

У проведеному дослідженні ми встановили, що високий рівень IL-6 дає можливість розглядати йо-

Таблиця 1. Порівняльна характеристика IL-1 $\beta$, TNF- $\alpha$ та IL-6 у хворих з еритематозною та деструктивними формами бешихи

\begin{tabular}{||c|c|c|c|c|c|c||}
\hline \multirow{2}{*}{ Цитокіни } & \multicolumn{3}{|c|}{ Еритематозна форма $\mathrm{n}=24$} & \multicolumn{3}{|c||}{ Деструктивна форма $\mathrm{n}=90$} \\
\cline { 2 - 7 } & \multicolumn{2}{|c|}{ строки дослідження } & \multicolumn{3}{|c||}{ строки дослідження } \\
\cline { 2 - 7 } & 1 доба & $7-8$ доба & $12-16$ доби & 1 доба & $7-8$ доба & $12-16$ доби \\
\hline IL-1ß пг/мл & $49,8 \pm 10,5$ & $36,8 \pm 9,8$ & $* *$ & $112,0 \pm 27,8 *$ & $42,6 \pm 9,3 *$ & $14,3 \pm 3,2$ \\
\hline TNF- $\alpha$ пг/мл & $42,9 \pm 8,5$ & $10,3 \pm 3,2$ & $* *$ & $66,8+22,3^{*}$ & $22,6 \pm 4,6^{*}$ & $13,9 \pm 4,5$ \\
\hline IL-6 пг/мл & $52,2 \pm 6,7$ & $38,2 \pm 2,4$ & $* *$ & $73,2 \pm 8,13^{*}$ & $72,8 \pm 9,3^{*}$ & $48,2 \pm 3,2$ \\
\hline \hline
\end{tabular}

Примітки: * - статистично достовірно порівняно з еритематозною формою $(\mathrm{p}<0,05)$;

** - хворі з еритематозною формою бешихи на 12-16 доби видужали та їх виписали зі стаціонару. 
го як маркер агресивності перебігу захворювання. Виявлено прямий кореляційний зв'язок $(\mathrm{r}=0,8925)$ між рівнем IL-6 та тяжкістю перебігу інфекційного ускладнення. Він дає можливість диференціювати розвиток локальної та генералізованої інфекції і визначати прогноз захворювання.

Можна вважати, що відмінності в патогенезі розвитку еритематозної та деструктивної форм бешихи полягає в більш значному і достовірному підвищенні прозапальних цитокінів (IL-1 $\beta$, TNF- $\alpha$, IL-6) у хворих із деструктивними формами порівняно з еритематозною формою захворювання.

Встановлено, що збільшення рівнів цитокінів IL-1 $\beta$, TNF- $\alpha$ та IL-6 у хворих із первинною та рецидивуючою бешихою в гострому періоді захворювання відбувається незалежно від кратності перебігу захворювання. При цьому спостерігається збереження високих рівнів даних цитокінів і в період ранньої реконвалесценції як у хворих із первинною бешихою, так і у хворих із рецидивуючою формою захворювання.

При аналізі профілю цитокінів у хворих з еритематозною формою залежно від кратності течії ми встановили, що у хворих з первинною бешихою рівні IL-1 $\beta$, TNF- $\alpha$ та IL-6 перевищують аналогічні показники у хворих із рецидивуючою бешихою в гострому періоді захворювання: IL-1 $\beta$ $((59,5 \pm 11,9)$ пг/мл і $(29,0 \pm 8,9)$ пг/мл відповідно) $(\mathrm{p}<0,05), \mathrm{TNF}-\alpha$ в період ранньої реконвалесценції $((15,5 \pm 5,2)$ пг/мг і $(3,8 \pm 3,2)$ пг/мл відповідно), IL-6 $((52,2 \pm 10,7)$ пг/мл і $(43,2 \pm 8,3)$ пг/мл відповідно) $(\mathrm{p}<0,05)$ (табл. 2).

При аналізі рівнів цитокінів у хворих із деструктивними формами бешихи залежно від кратності перебігу захворювання встановлено достовірне $(\mathrm{p}<0,05)$ збільшення IL-1 $\beta$ та IL-6 у хворих із первинною бешихою порівняно з рецидивуючою формою як в гострому періоді, так і в період ранньої реконвалесценції $((145,0 \pm 34,5)$ пг/мл і $(60,4 \pm 18,3)$ пг/мл відповідно) та $((19,5 \pm 8,8)$ пг/мл i $(14,8 \pm 4,8)$ пг/мл відповідно). Незважаючи на підвищені показники TNF- $\alpha$ у хворих із первинною бешихою достовірних відмінностей з рецидивуючою формою не встановлено $((46,1 \pm 18,0)$ пг/мл і $(34,3 \pm 13,8)$ пг/мл відповідно) (табл. 3).

Таким чином, у хворих з первинною еритематозною та деструктивними формами бешихи спо-

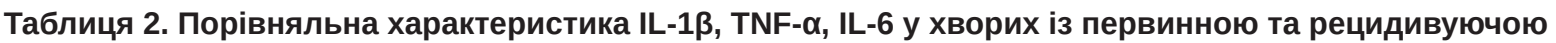
еритематозною формою бешихи

\begin{tabular}{||c|c|c|c|c|c|c||}
\hline \multirow{2}{*}{ Цитокіни } & \multicolumn{3}{|c|}{ Первинна форма $\mathrm{n}=24$} & \multicolumn{3}{c||}{ Рецидивуюча форма $\mathrm{n}=4$} \\
\cline { 2 - 7 } & \multicolumn{2}{|c|}{ строки дослідження } & \multicolumn{3}{c||}{ строки дослідження } \\
\cline { 2 - 7 } & 1 доба & $7-8$ доба & $12-16$ доби & 1 доба & $7-8$ доба & $12-16$ доби \\
\hline IL-1 $\beta$ пг/мл & $59,5 \pm 11,9$ & $28,8 \pm 9,5$ & $* *$ & $29,0 \pm 8,9 *$ & $24,0 \pm 8,2 *$ & $14,0 \pm 4,8$ \\
\hline TNF- $\alpha$ пг/мл & $32,9 \pm 8,5$ & $15,5 \pm 5,2$ & $* *$ & $26,8+10,2 *$ & $10,6 \pm 3,6 *$ & $3,8 \pm 3,2$ \\
\hline IL-6 пг/мл & $52,2 \pm 10,7$ & $38,2 \pm 9,4$ & $* *$ & $43,2 \pm 8,3 *$ & $24,8 \pm 9,3 *$ & $15,2 \pm 3,2$ \\
\hline \hline
\end{tabular}

Примітки: * - статистично достовірно порівняно з еритематозною формою (p<0,05);

** - хворі з еритематозною формою бешихи на 12-16 доби видужали та їх виписали зі стаціонару.

Таблиця 3. Порівняльна характеристика IL-1 $\beta$, TNF - $\alpha$ та IL-6 у хворих із первинною та рецидивними формами деструктивної бешихи

\begin{tabular}{||c|c|c|c|c|c|c||}
\hline \multirow{2}{*}{ Цитокіни } & \multicolumn{3}{|c|}{ Первинна форма n=90 } & \multicolumn{3}{c||}{ Рецидивуюча форма n=17 } \\
\cline { 2 - 8 } & \multicolumn{3}{|c||}{ строки дослідження } & \multicolumn{3}{c||}{ строки дослідження } \\
\cline { 2 - 8 } & 1 доба & $7-8$ доба & $12-16$ доби & 1 доба & $7-8$ доба & $12-16$ доби \\
\hline IL-1 $\beta$ пг/мл & $145,0 \pm 34,5$ & $48,8 \pm 9,5$ & $19,5 \pm 8,8$ & $60,4 \pm 18,3$ & $39,0 \pm 8,2$ & $14,8 \pm 4,8$ \\
\hline TNF- $\alpha$ пг/мл & $46,1 \pm 18,0$ & $25,5 \pm 5,2$ & $16,8 \pm 5,6$ & $34,3 \pm 13,8$ & $23,6 \pm 3,6$ & $13,8 \pm 4,6$ \\
\hline IL-6 пг/мл & $52,2 \pm 10,7$ & $38,2 \pm 9,4$ & $23,6 \pm 8,6$ & $43,2 \pm 8,3$ & $24,8 \pm 9,3$ & $15,2 \pm 3,2$ \\
\hline
\end{tabular}


стерігали значніше $(\mathrm{p}<0,05)$ підвищення рівнів цитокінів порівняно з рецидивуючою формою захворювання.

Висновки. 1. Встановлено закономірності динаміки змін прозапальних цитокінів IL-1 $\beta$, IL-6 i TNF- $\alpha$ при різних формах бешихи. При деструктивних формах бешихи виявлено достовірне підвищення IL-1 $\beta$, TNF- $\alpha$, IL-6 ( $<0,05)$, в гострому періоді хвороби порівняно з еритематозною, що

\section{СПИСОК ЛІТЕРАТУРИ}

1. Нейроиммуноэндокринная регуляция физиологических и патофизиологических процессов в коже / О. А. Башкина, М. А. Самотруева, А. К. Ажикова, Л. Р. Пахнова // Медицинская иммунология. - 2019. - № 21. - С. 807-820.

2. Бражник Е. А. Рожистое воспаление в хирургической практике / Е. А. Бражник, А. П. Остроушко // Научное обозрение. Медицинские науки. - 2016. - № 4. - С. 14-17.

3. Гопаца Г. В. Рожа: современное состояние проблемы / Г. В. Гопаца, Л. А. Ермакова // Научный альманах. - 2016. № 1-2. - С. 364-366.

4. Полиморфизм промоторного региона rs1800629 гена TNF $\alpha$ и его влияние на содержание фактора некроза опухолей альфа в крови здоровых лиц и больных рожей / А. С. Емельянов, А. Н. Емельянова, Б. С. Пушкарев, Ю. А. Витковский // Медицинская иммунология. - 2018. - Т. 20, № 3. - С. 411-416.

5. Коморбидность рожи и эндокринных заболеваний /

\section{REFERENCES}

1. Bashkina, O.A., Samotrueva, M.A., Azhikova, A.K., \& Pakhnova, L.R. (2019). Neyroimmunoendokrinnaya regulyatsiya fiziologicheskikh i patofiziologicheskikh protsessov v kozhe [Neuroimmunoendocrine regulation of the skin functioning]. Meditsinskaya immunologiya - Medical Immunology, 21, 807-820. DOI: 10.15789/1563-0625-2019-5-807-820 [in Russian].

2. Brazhnik, E.A., \& Ostroushko, A.P. (2016). Rozhistoye vospaleniye v khirurgicheskoy praktike [Erysipelas in a surgical practice]. Nauchnoe obozrenie. Meditsinskie nauki - Sci. Rev. Med. Sci., 4, 14-17 [in Russian].

3. Gopatza, G.V., \& Ermakova, L.A. (2016). Rozha: sovremennoye sostoyaniye problemy [Erysipelas: current condition of the problem]. Nauchnyy almanakh - Scientific Almanac, 1-2, 364341. DOI: 10.17117/na.2016.01.02.364 [in Russian].

4. Emelyanov, A.S., Emelyanova, A.N., Pushkarev, B.S., \& Vitkovskiy, Yu.A. (2018). Polimorfizm promotornogo regiona rs1800629 gena TNF $\alpha$ i ego vliyanie na soderzhanie faktora nekroza opukholey alfa v krovi zdorovykh lits i bolnykh rozhey [Promoter region rs1800629 TNF $\alpha$ polymorphism and its influence on tumor necrosis factor alpha concentration in blood of healthy individuals and patients with erysipelas]. Meditsinskaya immunologiya - Medical Immunology, 20 (3), 411-416. DOI: 10.15789/15630625-2018-3-411-416 [in Russian]. є одним з важливих патогенетичних механізмів у розвитку місцевого гнійного вогнища інфекції.

2. У хворих з первинною еритематозною та деструктивними формами встановлено достовірне ( $<<0,05)$ підвищення рівнів IL-1 $\beta$, TNF- $\alpha$ та IL-6 порівняно з рецидивуючими формами.

3. Динаміка змін вмісту цитокінів у сироватці крові у хворих на бешиху свідчить про залежність дисбалансу цих показників від тяжкості запального процесу.
Л. И. Ратникова, С. А. Шип, М. К. Беспалова, А. Р. Гарифанова // Научный альманах. - 2016. - № 53 (19). - С. 341-346. 6. Time to recognition of sepsis in the emergency department using electronic health record data: a comparative analysis of systemic inflammatory response syndrome, sequential organ failure assessment, and quick sequential organ failure assessment / P. A. Prasad, M. C. Fang, Y. Abe-Jones [et al.] // Crit. Care Med. - 2019. - Vol. 48 (2). - P. 200-209.

7. Surviving sepsis campaign: international guidelines for management of sepsis and septic shock: 2016 / A. Rhodes, L. E. Evans, W. Alhazzani [et al.] // Intensive Care Med. - 2017. - Vol. 43 (3). - P. 304-377.

8. Assessment of clinical criteria for sepsis: for the third international consensus definitions for sepsis and septic shock (Sepsis-3) / C. W. Seymour, V. X. Liu, T. J. Iwashyna [et al.] // JAMA. - 2016. - Vol. 23 (8). - P. 762-774.
5. Ratnikova, L.I., Ship, S.A., Bespalova, M.K., \& Garifanova, A.R. (2016). Komorbidnost rozhi i endokrinnykh zabolevaniy [Comorbidity of erysipelas and endocrine diseases]. Nauchnyy almanakh - Scientific Almanac, 3, 341-346. DOI: 10.17117/ na.2016.05.03.341 [in Russian].

6. Prasad, P.A., Fang, M.C., Abe-Jones, Y., Calfee, C.S., Matthay, M.A., \& Kangelaris, K.N. (2019). Time to recognition of sepsis in the emergency department using electronic health record data: a comparative analysis of systemic inflammatory response syndrome, sequential organ failure assessment, and quick sequential organ failure assessment. Crit. Care Med., 48 (2), 200-209. DOI: 10.1097/CCM.0000000000004132.

7. Rhodes, A., Evans, L.E., Alhazzani, W., Levy, M.M., Antonelli, M., Ferrer, R., ..., \& Dellinger, R.P. (2017). Surviving sepsis campaign: international guidelines for management of sepsis and septic shock: 2016. Intensive Care Med., 43 (3), 304-377. DOI: 10.1007/s00134-017-4683-6.

8. Seymour, C.W., Liu, V.X., Iwashyna, T.J., Brunkhorst, F.M., Rea, T.D., Scherag, A., ..., \& Angus, D.C. (2016). Assessment of clinical criteria for sepsis: for the third international consensus definitions for sepsis and septic shock (Sepsis-3). JAMA, 23 (8), 762-774. DOI: 10.1001/jama.2016.0288. 


\section{S. D. SHAPOVAL, L. A. VASYLEVSKA}

Zaporizhzhia Medical Academy of Postgraduate Education

\section{CLINICAL AND PATHOGENETIC SIGNIFICANCE OF PROINFLAMMATORY CYTOKINES INDICATORS IN PATIENTS WITH ERYSIPELAS}

The aim of the work: to determine the pathogenetic and clinical significance of proinflammatory cytokines in patients with various forms of erysipelas.

Materials and Methods. 114 case histories of patients who underwent inpatient treatment in the center of purulent-septic surgery in the Non-profit municipal enterprise "City Hospital No. 3" in Zaporizhzhia for the period 2019-2020 were analyzed retrospectively and prospectively.

According to the forms of the disease, patients were distributed as follows: erythematous - 24 (21.0\%), bullous - 28 (24.6\%), phlegmonous form - 48 (42.1\%), necrotic - 14 (12.3\%). Recurrent cases of the disease were observed in 21 patients. Among them: erythematous form -4 (16.7\%), in bullous $-5(17.9 \%)$, phlegmonous - 9 (18.7 \%), necrotic $-3(21.4 \%)$.

Results and Discussion. Regularities of dynamics of changes of proinflammatory cytokines IL-1 $\beta$, IL- 6 and TNF- $\alpha$ at various forms of erysipelas were established. The dynamics of changes in the content of cytokines in the serum of patients with erysipelas indicated the dependence of the imbalance of these indicators on the severity of the inflammatory process.

It was revealed a significant increase in IL- $1 \beta$, TNF- $\alpha$, IL-6 $(p<0,05)$ in destructive forms of erysipelas in the acute period of the disease compared with erythematous, which is one of the important pathogenetic mechanisms in the development of local purulent foci of infection. In patients with primary erythematous and destructive forms, a significant $(p<0.05)$ increase in the levels of IL- $1 \beta$, TNF- $\alpha$ and IL-6 compared with recurrent forms was noted.

Key words: erysipelas; cytokines; inflammation.

\section{С. Д. ШАПОВАЛ, Л. А. ВАСИЛЕВСКАЯ}

ГУ “Запорожская медицинская академия последипломного образования МОЗ Украины”

\section{КЛИНИКО-ПАТОГЕНЕТИЧЕСКОЕ ЗНАЧЕНИЕ ПОКАЗАТЕЛЕЙ ПРОВОСПАЛИТЕЛЬНЫХ ЦИТОКИНОВ У БОЛЬНЫХ РОЖЕЙ}

Цель работы: определение патогенетического и клинического значения провоспалительных цитокинов у больных различными формами рожи.

Материалы и методы. Ретроспективно и проспективно проанализированы 114 историй болезней пациентов, которые находились на стационарном лечении в центре гнойно-септической хирургии КНП “Городская больницы № 3” г. Запорожье за период 2019-2020 гг.

По формам заболевания больные были распределены следующим образом: эритематозная - 24 (21,0 \%), буллезная - 28 (24,6 \%), флегмонозная форма - 48 (42,1 \%), некротическая - 14 (12,3 \%). Рецидивы заболевания отмечено у 21 пациента. Из них при эритематозной форме - 4 (16,7 \%), при буллезной - 5 (17,9 \%), флегмонозной - 9 (18,7 \%), некротической - 3 (21,4 \%). Результаты исследований и их обсуждение. Установлены закономерности динамики изменений провоспалительных цитокинов IL-1ß, IL-6 и TNF- $\alpha$ при различных формах рожи. Динамика изменений содержания цитокинов в сыворотке крови у больных рожей свидетельствует о зависимости дисбаланса этих показателей от тяжести воспалительного процесса.

При деструктивных формах рожи выявлено достоверное повышение IL-1 $\beta$, TNF- $\alpha$, IL-6 (р<0,05), в остром периоде болезни по сравнению с эритематозной, что является одним из важных патогенетических механизмов в развитии местного гнойного очага инфекции. У больных с первичной эритематозной и деструктивными формами отмечено достоверное (р<0,05) повышение уровня IL-1 $\beta$, TNF- $\alpha$ и IL-6 по сравнению с рецидивирующими формами.

Ключевые слова: рожа; цитокины; воспаление. 